\title{
Holotypes of recently described species of Mexican mammals: where should they be?
}

Contrary to conventional perception, hundreds of mammalian species continue to be discovered and described around the world (Patterson 2000; Reeder et al. 2007). Many newly discovered species have been found by field biologists in previously poorly surveyed areas (Ceballos and Ehrlich 2009). Hence, fieldwork and scientific collecting are responsible for many discoveries, especially in tropical and semitropical regions (Patterson 2002; Reeder et al. 2007; Ceballos and Ehrlich 2009). Given that evidence indicates that this trend will continue (Patterson 2002), mammalogists must have knowledge of all laws and regulations that pertain to scientific collecting of mammals (Sikes et al. 2016), including those cases where specimens collected in the field are subsequently recognized as new species.

In Mexico, activities of scientific collecting of specimens of wild flora and fauna (not only mammals) have been regulated particularly by the Norma Oficial Mexicana NOM-126-ECOL-2000. This regulation establishes, for example, specifications to obtain permits issued by the Mexican government for scientific collecting in the country. In addition, the NOM-126-ECOL-2000 also regulates cases where specimens collected in Mexico are later designated as the name-bearing type of a nominal species (i. e., the holotype):

“5.11. En caso de que el titular de una autorización de colecta científica identifique que el material biológico colectado incluye una nueva especie depositará al menos el holotipo en alguna institución mexicana o colección científica registrada mexicana y dará aviso de ello a la Secretaría [de Medio Ambiente y Recursos Naturales, SEMARNAT]".

"5.11. In case the holder of a scientific collecting permit identifies that the biological material collected includes a new species, it shall deposit at least the holotype in a Mexican institution or Mexican scientific collection and shall notify the Secretary thereof. "

It should be noted that NOM-126-ECOL-2000 is mandatory for all those persons who carry out activities of scientific collecting in Mexican territory and entered into force in April 2001 (i. e., 60 days after the publication of this regulation). Consequently, all specimens collected in Mexico after April 2001 (using collecting permits provided by the Secretary), which are later designated as holotypes of a new species, should be housed in Mexican institutions. As an example, I describe the case of a species of rodent recently described from Nayarit, Mexico. In 2011, some individuals of pocket gophers were collected in Sierra del Nayar. Later, genetic analyses revealed that those individuals represent a previously unrecognized species, Thomomys nayarensis. An adult male was designated as the holotype (Louisiana State University Museum of Natural Science, LSUMZ 36794, Mathis et al. 2013). Given that pocket gophers were collected using a collecting permit issued by the Secretary, the holotype of T. nayarensis was properly sent from LSUMZ to a Mexican institution (Colección Nacional de Mamíferos, Universidad Nacional Autónoma de México, CNMA 45745).

Here, I specifically highlight the specification 5.11 in the NOM-126-ECOL-2000 because fieldwork is far from over and many more mammalian species await discovery in Mexico (Sánchez-Cordero et al. 2014). The discovery of at least four species of Mexican mammals whose holotypes were collected during this century support this idea. Unfortunately, this regulation is unclear in the case of someone other than the holder of the collecting permit can later designate as holotype a specimen, which should be clarified in future modifications of this regulation. Despite this, I hope that this letter serves as an invitation to students, investigators, and field technicians to become familiar with Mexican official regulations regarding the discovery and description of new species in the country.

LÁZARO GueVARA

Museo de Zoología Alfonso L. Herrera. Departamento de Biología Evolutiva. Facultad de Ciencias. Universidad Nacional Autónoma de México. Apartado Postal 70-399, CP. 04510, Ciudad de México, México. Email:Ilg@st.ib.unam.mx

\section{Literature cited}

Ceballos, G., and P. R. Ehrlich. 2009. Discoveries of new mammal species and their implications for conservation and ecosystem services. Proceedings of the National Academy of Sciences 106:3841-3846.

Mathis, V. L., M. S. Hafner, D. J. Hafner, And J. W. Demastes. 2013. Thomomys nayarensis, a new species of pocket gopher from the Sierra del Nayar, Nayarit, Mexico. Journal of Mammalogy 94:983-994.

Patterson, B. D. 2000. Patterns and trends in the discovery of new Neotropical mammals. Diversity and Distributions 6:145-151. Patterson, B. D. 2002. On the continuing need for scientific collecting of mammals. Mastozoología Neotropical 9:253-262.

Reeder, D. M., K. M. Helgen, AND D. E. Wilson. 2007. Global trends and biases in new mammal species discoveries. Museum of Texas Tech University 269:1-35.

Sánchez-Cordero, V., F. Botello, J. J. Flores-Martínez, R. A. Gómez-Rodríguez, L. Guevara, G. Gutiérrez-Granados, and A. Rodríguez-Moreno. 2014. Biodiversidad de Chordata (Mammalia) en México. Revista Mexicana de Biodiversidad 85:496-504.

Secretaría de Medio Ambiente y Recursos Naturales. 2001. Norma Oficial Mexicana NOM-126-SEMARNAT-2000, Que establece especificaciones para la realización de actividades de colecta científica de material biológico de especies de flora y fauna silvestres y otros recursos biológicos en el territorio nacional. Secretaría del Medio Ambiente y Recursos Naturales. México. 31 de enero de 2001.

Sikes, R. S., and Animal Care and Use Committee of the American Society of Mammalogists. 2016. 2016 Guidelines of the American Society of Mammalogists for the use of wild mammals in research and education. Journal of Mammalogy 97:663-688. 
192 THERYA Vol. 8 (3): 191-192 